\title{
Prognosis of glaucoma in relation to blindness at a university hospital
}

Prognóstico dos glaucomas em relação à cegueira em um serviço universitário

\author{
SebastiãoCronemberger ${ }^{1}$ \\ Lívia Flávia Sebe Lourenco ${ }^{2}$ \\ Lucas Carazza Silva ${ }^{3}$ \\ Nassim Calixto ${ }^{4}$ \\ Magda Carvalho Pires ${ }^{5}$
}

Trabalho realizado no Serviço de Glaucoma do Hospital São Geraldo (Hospital das Clínicas) - Universidade Federal de Minas Gerais (UFMG) - Belo Horizonte Minas Gerais - Brasil

${ }^{1}$ Professor Titular de Oftalmologia - Faculdade de Medicina da Universidade Federal de Minas Gerais - UFMG - Belo Horizonte (MG) - Brasil.

${ }^{2}$ Bolsista de Iniciação Científica (PIBIC - CNPq). Aluna do $12^{\circ}$ período de Curso de Graduação em Medicina Faculdade de Medicina da UFMG - Belo Horizonte (MG) - Brasil.

${ }^{3}$ Pós-graduando (Curso de Doutorado) do Departamento de Estatística da UFMG - Belo Horizonte (MG) Brasil.

${ }^{4}$ Professor Titular de Oftalmologia - Faculdade de Medicina da UFMG - Belo Horizonte (MG) - Brasil.

${ }^{5}$ Pós-graduanda (Curso de Doutorado) do Departamento de Estatística da UFMG - Belo Horizonte (MG) Brasil.

Correspondence to: Sebastião Cronemberger. Rua Martim de Carvalho, 410/501 - Belo Horizonte (MG) CEP 30190-090

E-mail: cronem@task.com.br

Recebido para publicação em 23.07.2008

Última versão recebida em 03.12.2008

Aprovação em 01.03.2009

Nota Editorial: Depois de concluída a análise do artigo sob sigilo editorial e com a anuência da Dra. Edméa Rita Temporini sobre a divulgação de seu nome como revisora, agradecemos sua participação neste processo.

\begin{tabular}{|c|}
\hline ABSTRACT \\
\hline 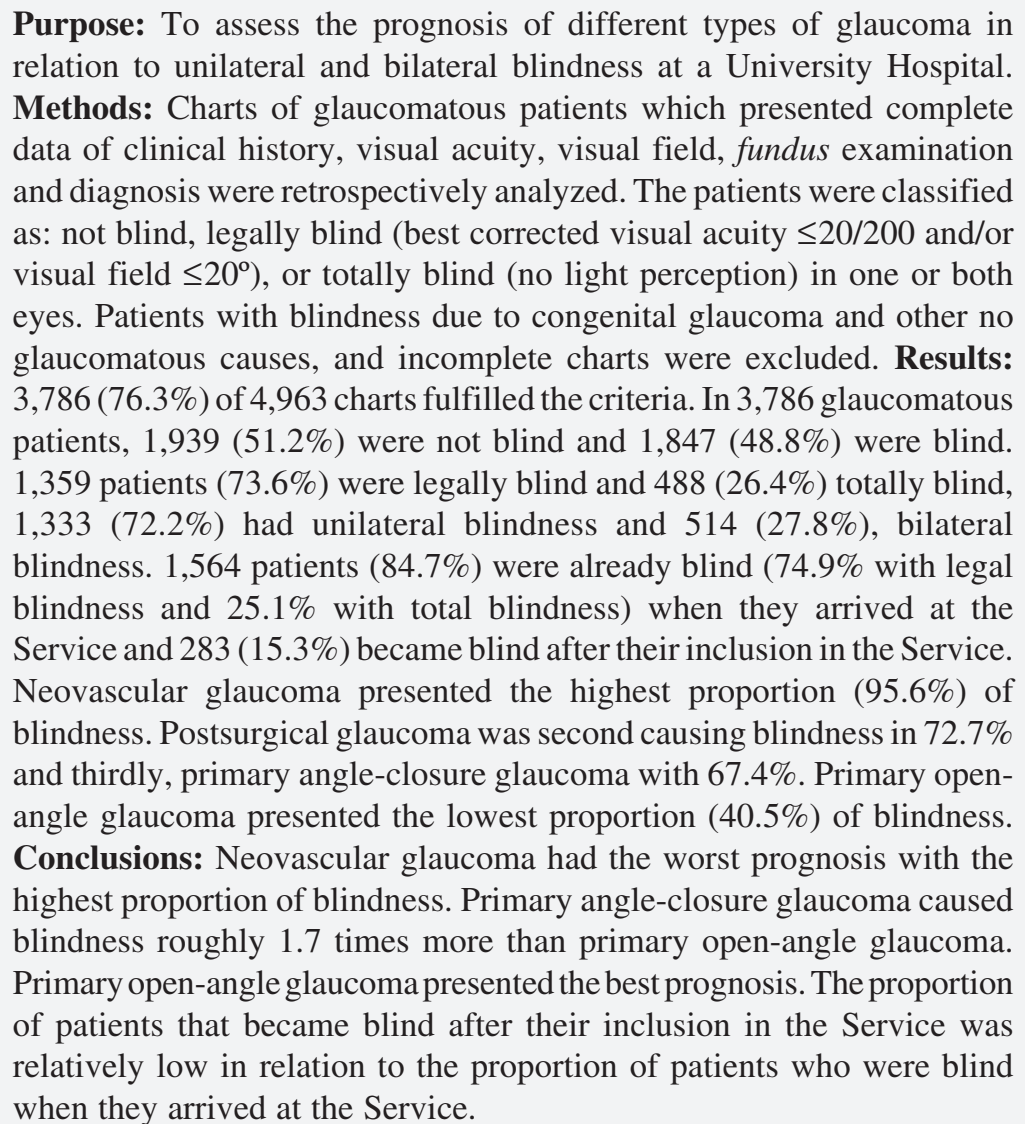 \\
\hline
\end{tabular}

Keywords: Blindness/diagnosis; Glaucoma/complications; Glaucoma/epidemiology; Prognosis

\section{INTRODUCTION}

Glaucoma is one of the greatest public health challenges that has become increasingly prevalent due to the advance of longevity. This disease affects approximately 67 million people in the world ${ }^{(1)}$. The Brazilian Council of Ophthalmology estimates the existence of close to 900 thousand glaucomatous people within a population of 169 million people. Among glaucomatous people, 720 thousand are asymptomatic and half are unaware of their disease $^{(2-4)}$.

According to the World Heath Organization (WHO), glaucoma is the second eye disease that causes blindness, responsible for $15 \%$ of blindness 
worldwide ${ }^{(1,5-6)}$. Blindness caused by glaucoma occurs in developing countries like Brazil due to the difficulties of access to health care institutions which lead to late diagnosis and treatment. Another cause is inadequate treatment due to various motives, principally the noncompliance of patients to their treatment owing to the impossibility of acquiring the antiglaucomatous drops. The seriousness of glaucoma is justified by the fact that it causes structural damage to the optic disc and irreversible loss of function that can trigger legal (best corrected visual acuity $\leq 20 / 200$ and/or visual field $\leq 20^{\circ}$ ), or total blindness (no light perception). Several types of glaucoma exist that are substantially different in relation to their evolution and prognosis for causing blindness. In the literature, very few papers have made a comparative study of blindness caused by different types of glaucoma ${ }^{(7-9)}$.

This paper evaluates the prognosis of glaucoma in relation to the frequency of unilateral and bilateral blindness caused by different forms of glaucoma.

\section{METHODS}

A retrospective analysis was done at the Glaucoma Service of the São Geraldo Hospital of glaucomatous patients' charts from 1959 to 2006. Only patients whose charts presented complete data of their clinical history, visual acuity (VA), visual field (VF), fundus examination and diagnosis were included. The patients were classified as: not blind, legally blind (VA $\leq 20 / 200$ under the best correction and/or VF $\leq 20^{\circ}$ according to $\mathrm{WHO}^{1}$ ), or totally blind (no light perception) in one or both eyes. Patients with blindness due to congenital glaucoma and other not glaucomatous causes, and incomplete charts were excluded. For each patient, we recorded the type of glaucoma that caused the blindness in one or both eyes considering that some types of glaucoma can occur in only one eye. We assessed the type of glaucoma that caused blindness and the type of blindness (legal or total), the affected eye along with the age.

The statistical analysis was done by the $\mathrm{Z}$ test for proportions, Pearson chi-square test, Student's $t$ test and MannWhitney test (SPSS 13.0).

This study was approved by the Research Ethics Committee of the Federal University of Minas Gerais.

\section{RESULTS}

We analyzed 4,963 glaucomatous patients' charts, but only $3,786(76.3 \%)$ fulfilled the inclusion criteria. In 3,786 glaucomatous patients, $1,939(51.2 \%)$ were not blind and 1,847 (48.8\%) were blind due to different types of glaucoma. Table 1 demonstrates that blindness was associated with the type of glaucoma. We observed that the proportion of legal or total blindness was significantly higher $(\mathrm{P}$-value $<0.001)$ in patients with secondary glaucoma $(70.3 \%)$ compared to patients with primary glaucoma $(44.1 \%)$. Secondary glaucoma also presented a significantly higher proportion $(35.0 \%)$ of total blindness than primary glaucoma $(23.5 \%)$ (P-value $<0.001)$. In 1,847 blind patients, $1,359(73.6 \%)$ were legally blind and $488(26.4 \%)$ were totally blind, $1,333(72.2 \%)$ had monocular blindness and $514(27.8 \%)$ had binocular blindness. The results of the proportion and type of blindness (legal or total) in each form of primary and secondary glaucoma are shown in Table 2. Primary open-angle glaucoma (POAG) was the most frequent type of glaucoma with 2,698 (71.3\%) patients but it was responsible for the lowest proportion of blindness (40.5\%), with $80.8 \%$ legally blind. Primary angle-closure glaucoma (PACG) was diagnosed in 417 (11.0\%) patients and secondary glaucoma in $671(17.7 \%)$ patients. In the group with secondary glaucoma there were 215 (32.0\%) patients with traumatic glaucoma, 203 (30.3\%) with neovascular glaucoma (NVG), 133 (19.8\%) with postsurgical glaucoma, and 120 $(17.9 \%)$ with different types of secondary glaucoma. These are classified as other secondary glaucoma. Included are: glaucoma associated with uveitis (38 patients), glaucoma associated with pseudoexfoliation (25 patients), Sturge-Weber syndrome (22 patients), corticosteroid-induced glaucoma (20 patients), Ice syndrome (11 patients), and glaucoma due to increased venous pressure (4 patients). Again, we observed that the proportion of blindness is associated with the type of glaucoma. NVG presented the highest proportion of blind patients $(95.6 \%)$ followed by postsurgical glaucoma (72.2\%), PACG (67.4\%), and traumatic glaucoma (60.9\%). The type of blindness was also related to the type of glaucoma. Once more, NVG presented the highest proportion of patients with total blindness $(55.2 \%)$, followed by PACG $(40.2 \%)$, other secondary glaucoma (25.5\%), and traumatic glaucoma (21.4\%). On the other hand, POAG presented the highest proportion of legal blindness (80.8\%). Table 3 demonstrates the proportion of blind and not blind glaucomatous patients at their arrival at the Glaucoma Service. In 3,786 glaucomatous patients, 1,564 $(84.7 \%)$ were already blind when they arrived at the Service (74.9\% with legal blindness and $25.1 \%$ with total blindness) and $283(15.3 \%)$ became blind after their inclusion in the Service. The patients who were blind at the time of their arrival presented the following types of glaucoma: NVG, with the highest proportion (84.7\%), postsurgical glaucoma (66.9\%), and PACG (56.6\%). On the other hand, patients with POAG and those in the secondary glaucoma group presented the lowest proportion of blindness at their arrival, respectively $33.4 \%$ and $37.5 \%$. Table 4 demonstrates what happened to the glaucomatous patients after their inclusion in the Service. It is important to emphasize that depending on the type of glaucoma, each patient was clinically and/or surgically treated. In spite of this, some patients did develop blindness although the proportion of blindness was significantly lower $(15.3 \%)$ than that of the patients who were blind when they arrived at the Service (84.7\%). It is important to highlight that 62 (21.9\%) of 283 patients who developed blindness after their inclusion in the Service, abandoned the treatment for an interval of time of at least one year before becoming blind. The average time for the occurrence of 


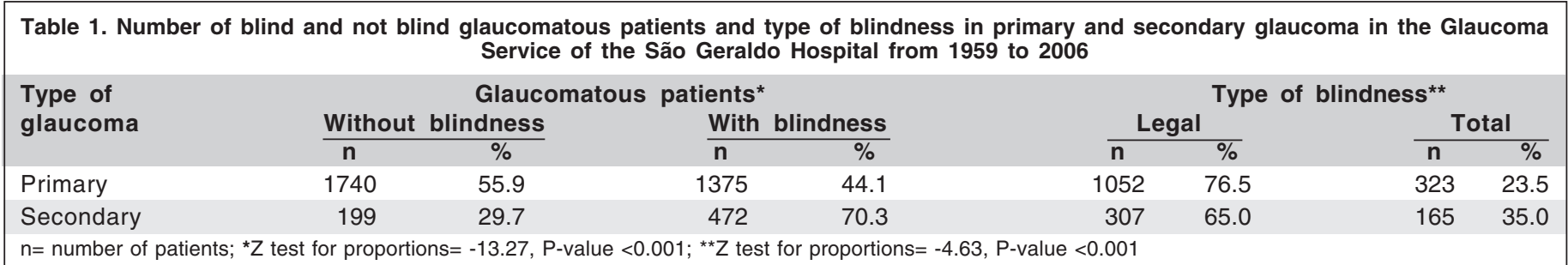

\begin{tabular}{|c|c|c|c|c|c|c|c|c|}
\hline \multirow{3}{*}{$\begin{array}{l}\text { Type of } \\
\text { glaucoma }\end{array}$} & \multicolumn{4}{|c|}{ Glaucomatous patients* } & \multicolumn{4}{|c|}{ Type of blindness ${ }^{\star *}$} \\
\hline & \multicolumn{2}{|c|}{ Without blindness } & \multicolumn{2}{|c|}{ With blindness } & \multicolumn{2}{|c|}{ Legal } & \multicolumn{2}{|c|}{ Total } \\
\hline & $\mathbf{n}$ & $\overline{\%}$ & $\mathbf{n}$ & $\%$ & $\bar{n}$ & $\overline{\%}$ & $\mathbf{n}$ & $\%$ \\
\hline POAG & 1604 & 59.5 & 1094 & 40.5 & 884 & 80.8 & 210 & 19.2 \\
\hline PACG & 136 & 32.6 & 281 & 67.4 & 168 & 59.8 & 113 & 40.2 \\
\hline Traumatic GI. & 84 & 39.1 & 131 & 60.9 & 103 & 78.6 & 28 & 21.4 \\
\hline Post-surgical GI. & 37 & 27.8 & 96 & 72.2 & 79 & 82.3 & 17 & 17.7 \\
\hline Neovascular GI. & 9 & 4.4 & 194 & 95.6 & 87 & 44.8 & 107 & 55.2 \\
\hline Other Sec GI. & 69 & 57.5 & 51 & 42.5 & 38 & 74.5 & 13 & 25.5 \\
\hline
\end{tabular}

\begin{tabular}{|c|c|c|c|c|c|c|}
\hline \multirow[t]{2}{*}{$\begin{array}{l}\text { Type of } \\
\text { glaucoma }\end{array}$} & \multicolumn{2}{|c|}{$\begin{array}{l}\text { Blind patients } \\
\text { at the arrival }\end{array}$} & \multicolumn{2}{|c|}{$\begin{array}{l}\text { Not blind patients } \\
\text { at arrival }\end{array}$} & \multirow[t]{2}{*}{$\begin{array}{l}\text { Chi-square } \\
\text { test }\left(\chi^{2}\right)\end{array}$} & \multirow[t]{2}{*}{ P-value } \\
\hline & n & $\%$ & $\mathbf{n}$ & $\%$ & & \\
\hline POAG & 902 & 33.4 & 1796 & 66.6 & 296.23 & $<0.001$ \\
\hline PACG & 236 & 56.6 & 181 & 43.4 & 7.25 & 0.007 \\
\hline Traumatic Gl. & 120 & 55.8 & 95 & 44.2 & 2.91 & 0.088 \\
\hline Post-surgical GI. & 89 & 66.9 & 44 & 33.1 & 15.23 & $<0.001$ \\
\hline Neovascular GI. & 172 & 84.7 & 31 & 15.3 & 97.94 & $<0.001$ \\
\hline Other Sec Gl. & 45 & 37.5 & 75 & 62.5 & 7.56 & 0.008 \\
\hline
\end{tabular}

\begin{tabular}{|c|c|c|c|c|c|c|c|}
\hline \multirow[t]{2}{*}{$\begin{array}{l}\text { Type of } \\
\text { glaucoma }\end{array}$} & \multicolumn{2}{|c|}{$\begin{array}{l}\text { Patients who did } \\
\text { not develop blindness }\end{array}$} & \multicolumn{2}{|c|}{$\begin{array}{c}\text { Patients who } \\
\text { developed blindness }\end{array}$} & \multirow[t]{2}{*}{$\begin{array}{c}\text { Treatment average } \\
\text { time (yrs.) }\end{array}$} & \multirow[t]{2}{*}{$\begin{array}{l}\text { Chi-square } \\
\text { test }\left(\chi^{2}\right)\end{array}$} & \multirow[t]{2}{*}{ P-value } \\
\hline & $\mathbf{n}$ & $\%$ & $\mathbf{n}$ & $\%$ & & & \\
\hline POAG & 1604 & 89.3 & 192 & 10.7 & 8.4 & 1110.10 & $<0.001$ \\
\hline PACG & 136 & 75.1 & 45 & 24.9 & 6.2 & 45.75 & $<0.001$ \\
\hline Traumatic Gl. & 84 & 88.4 & 11 & 11.6 & 3.0 & 56.09 & $<0.001$ \\
\hline Post-surgical GI. & 37 & 84.1 & 7 & 15.9 & 8.7 & 20.45 & $<0.001$ \\
\hline Neovascular GI. & 9 & 29.0 & 22 & 71.0 & 1.6 & 5.45 & 0.020 \\
\hline Other Sec Gl. & 69 & 92.0 & 6 & 8.0 & 5.1 & 53.29 & $<0.001$ \\
\hline
\end{tabular}

blindness was different for each type of glaucoma. The average time for patients with POAG was the longest (8.4 years), whereas it was the shortest (1.6 years) for NVG.

The distribution of glaucomatous patients according to the eye affected by blindness was the following. In cases of binocular blindness, a statistically significant correlation (Pearson chi-square test $\left(\chi^{2}\right)=87.0 ;$ P-value $<0.001$ ) was observed between the type of glaucoma and the blind eye (monocular or binocular blindness). POAG, other secondary glaucoma, and NVG presented the highest proportion of bila- 
teral blindness, respectively $35.0 \%, 25.5 \%$, and $25.3 \%$. On the other hand, traumatic glaucoma, postsurgical glaucoma and PACG presented the highest proportion of unilateral blindness, respectively $94.7 \%, 84.4 \%$, and $83.3 \%$. However, no correlation was found between the type of glaucoma and the affected eye in cases of monocular blindness (Pearson chi-square test $\left(\chi^{2}\right)=3.7$; P-value $=0.716$ ).

The age was presented as a possible risk factor for blindness in patients with POAG, PACG, and traumatic glaucoma. In these groups, the age of the patients who developed blindness was significantly higher (Student's $t$ test $=9.62$; P-value $<0.001$ for POAG; Student's $t$ test $=3.48$; P-value $=0.001$ for PACG; Student's $t$ test $=3.18$; P-value $=0.002$ for traumatic glaucoma) than the age of those patients without blindness. Patients with blindness due to POAG also presented the highest age mean (63.7 years). On the other hand, patients with blindness due to traumatic glaucoma presented the lowest age mean (41.7 years). In patients with NVG, postsurgical glaucoma and other secondary glaucoma, the age of the patients who developed blindness was not significantly higher (P-value> 0.05) than the age of those patients without blindness.

\section{DISCUSSION}

This study was done at the São Geraldo Hospital, Federal University of Minas Gerais, where patients with many different ocular diseases receive treatment. In general; the Hospital's patients have advanced or severe ocular diseases. As a tertiary public hospital, a great number of its patients have low average social and economic conditions. In consequence, these patients have little access to information on how to deal with their health. In agreement with other authors ${ }^{(2-4)}$, many patients know nothing about ocular diseases that can cause blindness such as glaucoma. Glaucoma is an asymptomatic eye disease and this important factor is responsible for patients to seek treatment only when the disease is in an advanced stage. These facts explain the findings of this paper: a high proportion (48.8\%) of blindness caused by glaucoma as well as a very high proportion $(84.7 \%)$ of patients who were already blind when they arrived at the Service. These findings are similar to those found by a Brazilian study ${ }^{(10)}$, in which the authors reported that $40(83.3 \%)$ of 48 eyes were already legally blind when they were examined for the first time. Another Brazilian study ${ }^{(1)}$ reported a smaller proportion of blind patients $(51.8 \%$ with unilateral blindness and $33.3 \%$ with bilateral blindness) when they arrived at their Service. The criterion for blindness was a visual acuity $<20 / 200$. In relation to the type of glaucoma, that paper ${ }^{(11)}$ found that $90.9 \%$ of patients with NVG, $75.0 \%$ of patients with uveitic glaucoma and $60.0 \%$ of patients with glaucoma associated with pseudoexfoliation were already blind when they arrived at the Service. In the present paper, NVG $(84.7 \%)$, postsurgical glaucoma (66.9\%), and PACG (56.6\%) were the types of glaucoma that presented the highest proportion of patients who were already blind when they arrived at the Glaucoma Service.
In this study, we consider the legal or total blindness of one or both eyes of each patient because some types of glaucoma can occur in only one eye or asymmetrically in both eyes of one patient. The data of this paper demonstrate that POAG was obviously more prevalent $(71.3 \%)$ than other types of glaucoma, which is in agreement with other publications ${ }^{(2,4,6,9-14)}$. However, less than a half of POAG patients $(40.5 \%)$ presented blindness. This type of glaucoma also presented the lowest proportion of total blindness (19.2\%) (Table 2). The fact that POAG is always bilateral could explain why it is responsible for the highest proportion (35.0\%) of binocular blindness. In relation to age, blindness due to POAG presented the oldest mean age (63.7 years) among all glaucomatous patients. Other important findings related to POAG are: the lowest proportion (33.4\%) of patients who were already blind when they arrived at the Service (Table 3), and one of the lowest proportions (10.7\%) of patients who became blind with the second longest average time of treatment ( 8.4 years) (Table 4$)$. These findings are in accordance with the highest frequency of POAG because of aging and the slow and insidious evolution of this disease. Based on all of the above findings, we can conclude that POAG has the best prognosis in relation to blindness. PACG was another primary glaucoma studied which also presented important findings. In relation to age, it had the second highest average (62.7 years). This average is a little higher than that reported in patients during the crisis of acute angle-closure (58.9 years) ${ }^{(15)}$. However, and most important is the fact that PACG caused 1.7 times more blindness than POAG according to some authors ${ }^{(15)}$. In this paper, we find that PACG caused legal or total blindness in $67.4 \%$ of the patients and this type of glaucoma has the second highest proportion of total blindness (40.2\%). PACG also presented a higher proportion (56.6\%) than POAG of patients who were already blind when they arrived at the Service. A disproportion is observed in the fact that PACG is the leading cause of bilateral blindness in China ${ }^{(5)}$, taking into consideration that this type of glaucoma can be prevented if adequate clinical or surgical treatment is provided.

In relation to unilateral and bilateral blindness, POAG, other secondary glaucoma, and NVG presented the highest proportion of bilateral blindness, respectively $35.0 \%$, $25.5 \%$, and $25.3 \%$. Unilateral blindness was more common in traumatic glaucoma, postsurgical glaucoma and PACG, respectively $94.7 \%, 84.4 \%$, and $83.3 \%$. These findings are in disagreement with those of one paper in which PACG was responsible for $91 \%$ of bilateral glaucoma blindness in China $^{(5)}$.

In this paper, charts of primary or secondary congenital glaucoma were excluded due to the lack of complete data about visual acuity and visual field in childhood.

A very important finding was the proportion of legal or total blindness significantly higher $(\mathrm{P}-\mathrm{value}<0.001)$ in patients with secondary glaucoma compared to those with primary glaucoma, respectively $70.3 \%$ and $44.1 \%$ (Table 1 ). Secondary glaucoma also presented a significantly higher 
proportion $(35.0 \%)$ of total blindness than primary glaucoma $(23.5 \%)$ (P-value $<0.001)$. In this type of glaucoma, the average age of the blind patients was lower than in those with primary glaucoma. Patients with blindness due to traumatic glaucoma presented the lowest mean age (41.7 years). This finding has a great importance. First, because the occurrence of blindness in young patients causes limitations and, consequently, greater social and economic loss. Second, because this type of glaucoma presents a faster evolution toward blindness than POAG (Table 4). One important finding is related to postsurgical glaucoma which presented a high proportion $(67.0 \%)$ of patients who were blind when they arrived in the Service. In NVG, the following findings are noteworthy: we have the highest proportion of blind patients (95.6\%), including those with total blindness $(55.2 \%)$; the highest proportion $(71 \%)$ of patients that developed blindness in the shortest average time (1.6 years) after their treatment in the Service. In accordance with other authors ${ }^{(2)}$, NVG presented the worst prognosis.

The results of the present paper confirm the urgent necessity for primary and secondary measures of glaucoma prevention worldwide to be established with the objective of reducing the irreversible blindness caused by this disease ${ }^{(16-18)}$.

\section{CONCLUSION}

The neovascular glaucoma had the worst prognosis with the highest proportion of blindness. Primary angle-closure glaucoma caused blindness roughly 1.7 times more than primary open-angle glaucoma. Primary open-angle glaucoma presented the best prognosis. The proportion of patients that became blind after their inclusion in the Service was relatively low in relation to the proportion of patients who were blind when they arrived at the Service.

The limitations of this study are due to information based on the charts.

\section{RESUMO}

Objetivo: Avaliar o prognóstico de diferentes tipos de glaucoma como causa de cegueira monocular e binocular num Hospital Universitário. Métodos: Foram analisados retrospectivamente os prontuários de portadores de glaucoma que possuíam dados completos de história clínica, acuidade visual, campo visual, fundo de olho e diagnóstico. Os pacientes foram classificados como: não portadores de cegueira e portadores de cegueira legal (melhor acuidade visual corrigida $\leq 0,1 \mathrm{e} / \mathrm{ou}$ campo visual $\leq 20^{\circ}$ ), ou total (ausência de percepção luminosa) em um ou ambos os olhos. Foram excluídos os pacientes com prontuários incompletos, com cegueira devida a glaucoma congênito e outras causas de cegueira não glaucomatosa. Resultados: Três mil setecentos oitenta e seis $(76,3 \%)$ de 4.963 prontuários preencheram os critérios. De 3.786 pacientes glaucomatosos, 1.939 (51,2\%) não apresentavam cegueira e 1.847 (48,8\%) eram cegos. Mil trezentos cinquenta e nove pacientes $(73,6 \%)$ apresentavam cegueira legal e 488 $(26,4 \%)$ cegueira total, $1.333(72,2 \%)$ tinham cegueira unilateral e $514(27,8 \%)$, bilateral. Mil quinhentos sessenta quatro pacientes $(84,7 \%)$ já eram cegos $(74,9 \%$ com cegueira legal e $25,1 \%$ com cegueira total) quando chegaram ao Serviço e apenas $283(15,3 \%)$ tornaram-se cegos após a sua matrícula no Serviço. O glaucoma neovascular apresentou a maior proporção $(95,6 \%)$ de cegueira. O glaucoma pós-cirúrgico foi o segundo que mais causou cegueira $(72,7 \%) \mathrm{e}$, em terceiro lugar, o glaucoma primário de ângulo fechado com $67,4 \%$. O glaucoma primário de ângulo aberto foi o que apresentou a menor proporção de pacientes com cegueira $(40,5 \%)$. Conclusões: $\mathrm{O}$ pior prognóstico coube ao GNV (maior proporção de pacientes cegos e com cegueira total), seguido pelo glaucoma póscirúrgico e pelo GPAF que causou cegueira aproximadamente 1,7 vezes mais que o GPAA. O melhor prognóstico recaiu no GPAA (menor proporção de pacientes cegos). A proporção de pacientes que ficaram cegos após a matrícula no Serviço foi muito baixa em relação à de pacientes que já chegaram cegos.

Descritores: Cegueira/diagnóstico; Glaucoma/complicações; Glaucoma/epidemiologia; Prognóstico

\section{REFERENCES}

1. Resnikoff S, Pascolini D, Etya'ale D, Kocur I, Pararajasegaram R, Pokharel GP, et al. Global data on visual impairment in the year 2002. Bull World Health Organ. 2004;82(11):844-51.

2. Mello PA, Melo Junior LA. Glaucoma dos nossos dias: revendo conceitos e custos. Rev Bras Oftalmol. 2003;62(9):669-77.

3. Costa VP, Vasconcelos JPC, Pelegrino M, Kara-José N. O que os pacientes sabem sobre o glaucoma? Arq Bras Oftalmol. 1995;58(1):36-41.

4. Silva MJ, Temporini ER, Neustein I, Araújo ME. Conhecimentos sobre prevenção e tratamento de glaucoma entre pacientes de unidade hospitalar. Arq Bras Oftalmol 2004;67(5):785-90.

5. Foster PJ, Johnson GJ. Glaucoma in China: how big is the problem? Br J Ophthalmol. 2001;85(11):1277-82. Comment in: Br J Ophthalmol. 2001;85(11): 1271-2.

6. Standefer JE. Glaucoma is second leading cause of blindness globaly. In focus [Internet]. 2004 [cited 2009 Feb 23];82:887-8. Available from: http:// www.who.int/bulletin/bulletin_board/83/infocus11041/en/index.html

7. Urbano AP, Freitas TG, Arcieri ES, Urbano AP, Costa VP. Avaliação dos tipos de glaucoma no Setor de Oftalmologia da UNICAMP. Arq Bras Oftalmol. 2003;66(1):61-5.

8. Congdon N, O'Colmain B, Klaver CC, Klein R, Muñoz B, Friedman DS, Kempen J, Taylo HR, Mitchell P; Eye Diseases Frequency Research Group. Causes and frequency of visual impairment among adults in the United States. Arch Ophthalmol. 2004;122(4):477-85.

9. Trautner C, Haastert B, Richter B, Berger M, Giani G. Incidence of blindness in Southern Germany due to glaucoma and degenerative conditions. Invest Ophthalmol Vis Sci. 2003;44(3):1031-4.

10. Gullo RM, Costa VP, Bernardi L, Kara-José N. Condições visuais de pacientes glaucomatosos em um hospital universitário. Arq Bras Oftalmol. 1996;59(2): $147-50$.

11. Rodrigues AC, Silva MR, Schellini SA. Número de olhos cegos por glaucoma detectado em primeira consulta num hospital universitário. Arq Bras Oftalmol. 1998;61(5):572-8.

12. Oliveira A, Paranhos Junior A, Prata Junior JA. Características dos pacientes atendidos pela primeira vez no Setor de Glaucoma da Universidade Federal de São Paulo - UNIFESP. Arq Bras Oftalmol. 2003;66(6):785-90. 
13. Hattenhauer MG, Johnson DH, Ing HH, Herman DC, Hodge DO, Yawn BP, et al. The probability of blindness from open angle glaucoma. Ophthalmology. 1998;105(11):2099-104. Comment in: Ophthalmology. 1999;106(11):2039-41.

14. Calixto N. Epidemiologia do glaucoma. Belo Horizonte; 1997. (comunicação pessoal).

15. Lai JS, Liu DT, Tham CC, Li RT, Lam DS. Epidemiology of acute primary angle-closure glaucoma in the Hong Kong Chinese population: prospective study. Hong Kong Med J. 2001;7(2):118-23.
16. Costa VP, Almeida GV, Kara-José N. Prevenção da cegueira por glaucoma. Arq Bras Oftalmol. 1998;61(3):356-60.

17. Hattenhauer MG, Johnson DH, Herman DC, Hodge DO, Gray DT. Half empty or half full?. Arch Ophthalmol. 2000;118(6):861-2. Comment in: Arch Ophthalmol. 1999;117(9):1211-5; Arch Ophthalmol. 1999;117(9):1236-7.

18. World Health Organization. Strategies for the prevention of blindness in national programmers; a primary healthy care approach. $2^{\text {nd }}$ ed. Geneva: WHO 1997. 